\title{
Literary Genre in Tapak Lapan Malay Economic System
}

\author{
Elmustian, Adli Hirzan \\ Universitas Riau, Universitas Kebangsaan Malaysia \\ elmustian@lecturer.unri.ac.id
}

\begin{abstract}
Literature to become fused (inherent) with the Malay society in Riau. One of the aspects is seen from the process of fusing between genre and the economic system of Tapak Lapan. This study was conducted by the qualitative method with descriptive approach. Determination of the informants is done purposively. Data are collected through interviews, observations, and analysis of evidence or objects. The results of the study indicate that literature exists in the economic system of Tapak Lapan. Literature as something important in playing the function of entertainer, education, and merit in the life of Malay society. Literature as a way of speaking Malay society in everyday life, and etc. The implications of this research on literary science can be a relevant reference for further research. For educational institutions, this research can be used as teaching material or reading material in literature and culture lectures. For creative institutions, this research becomes a guide for exploration in contemporary works. For the government to be a reference in developing Malay economy.
\end{abstract}

Keywords-Malay literary genres; economic system; Tapak Lapan; Malay society.

\section{INTRODUCTION}

Creation of cultural expression texts in Riau colored whole cultural landscape in space of society life. Literature is present in the economic system termed as Tapak Lapan. Literary interwoven in conjunction with the season cycle. Literature is inherent in the society traditional game. Literature is inherent in everyday life cycles. Literature sublimated in various rituals and ceremonies. The Genre of literature inherent in the initiation of life. And, literature continues on transmission and transformation activities of the text.

Early cultural expression of the Malays society ancestors exists in orality, with literature as the highest achievement of the intellect. Their early literature was gathered in cultural actors of Malay society, precisely at the center of authority and center of memory that settled in the traditional village. It is as a dignity and communal property passed down from generation to generation, noble and practiced. As a cultural expression, literary texts became the starting point of cultural development until today.

The next development is culture wave of Jawi literacy or Malay-speaking Arabic literacy tradition, which is estimated to take place beginning in the 13th century until the end of the 20th century. The cultural expression form of these Persian Arab influences gives another branch of Malay society cultural expression history that is literacy tradition. Not just media delivery like tools, pedestals, and text, but until the storage is changing form. The form and expression form also develops significantly. So, this time we see various literature work living in living space of the Malay society with various dynamics.

Malay-speaking regions produced prolific and creative works in various genres (Junus, 1998; Chambert-Loir, 1999; Braginsky, 1998; Koster, 2011; and Fang, 2011). Their studies and this paper strongly disagree with Hans Overbeck's statement that Malay literature is dead (Koster, 2011). With the results of their research that dug all their power and then recognition with honor what they compose by calling it 'Riau School' for a collection of Classical Malay literature works. V.I. Braginsky (1998) even supports Winsted who claimed that the distinctiveness of Malay literature by labeling 'sect of Riau literary'.

Desire to discuss in full and deep about oral expression event in Malay world at Riau as dives into a very deep and wide ocean, and we will be useless because it arises on the surface with sad and hopeful. Therefore, this discussion limits to the above-mentioned topics, that is literature as the crown headline and is related to the economic system of Tapak Lapan.

\section{METHODS}

Culture is understood as a human way in living life. Harris (1968) with a cultural concept which he described as something that is expressed in various patterns of behavior related to the owner or certain groups of society such as adat (custom). In fulfilling the basic needs of Malay society use the economic system of Tapak Lapan. Hamidy (1986) states that the system depends on nature and environment. In accordance with the naming, Tapak Lapan economy divided into eight kinds of livelihood, that is 1) farming (agriculture), 2) Breeding (rearing), 3) catching fish (fishery), 4) beniro (slicing sugar-palm (Arenga pinnata) or coconut) or agroindustry, 5) pick up or collecting forest or marine products (forestry), 6) gardening perennial plant or simply perennial (plantations), 7) carpenters, and 8) trade (trading). 
Malay society at Riau in running the system, literature is placed inbound (inherently) with activities of the economic society. Saleh (2006) describes literature function as the most important Malay expression tool because it includes national values such as religious works, customs, law, history, genealogy, and etc. Wellek and Warren (2014) also, interpret literature as a text or braided meaning is turned on by events described in the language. literary genre describes various expressions of artistic and imaginative facts as manifestations of human life that have a positive effect on society's lives. Translating Plato, literature form as an imitation result (mimesis) which is designed more artistic (Esten, 1978). Therefore, literature is seen as something that comes from human imaginative creativity with the purpose provides values in life. Koster (2011) examines the literary system and explains the function of literature in life, such as the function of entertainer, education, and spiritual perfection. In that connection, referring to the same motif, Benveniste- experience (discourse) and narratives (historie) - literature in Tapak Lapan economy of Malay society can be seen as a way to achieve certain goals.

This research was conducted qualitatively with descriptive approach. Creswell (2003) describes qualitatively as a way to examine, understand, and interpret carefully. Moleong (2010) explains the rules that are meant to understand phenomena experienced by research subjects such as behavior, perception, motivation, action, and etc., holistically, and by way of description in words, sentences, and languages form on a specific context that is natural and by utilizing various natural methods. Research instruments refer to Esterberg (2002) and Sugiyono (2012) about meeting two society to exchange information and ideas through interviews to gain meaning in a particular topic. In-depth interviews are conducted as one of the strategies for main data collection. Questions in semi-structured interviews designed by interview protocols.

Research informants were determined by purposive technique. Chua Yan Piaw (2006) and Gay (1996) purposive techniques can be applied in a group of subjects that runs the Malay society life. The requirements of research informants are the society of Malay Riau, Malay economic actors, as leaders (Datuk ${ }^{1}$, chief and experts in their culture), and men and women who are above 50 years old. Data collection techniques refer to qualitative studies. Researchers as designers, implementer of data collection, analysis, interpretation of data, as well as a reporter of study result (Moleong, 2010). Validity checks and data validity are performed before data analysis is performed. Triangulation is conducted on various sources of data (interviews, observations, and evidence analysis), being in the field in relatively long duration, and collaborating researchers with informants. Bogdan and Biklen (2003) describe data analysis, ie effort done as a way of working with data, organizing data, grouping data, synthesizing data, finding and finding patterns of study objectives, finding what is important and what is learned, and formulating conclusions.

\title{
III. FINDING AND DISCUSSION
}

The mention of Tapak Lapan is commonly used in Malay society in Riau, such as studies that have been pioneered by Malay thinkers UU. Hamidy (2004), followed by Elmustian and Edyanus Herman Halim on the study in 2013. The Tapak Lapan are agriculture, breeding, fishery, forestry, agroindustry, gardening, carpenters, and trading.

\section{Agriculture}

One of Tapak Lapan in the Malay economic system is agriculture. Almost overall in farming stages use the literary expression. Starting on land clearing used spells with various variants of the genre that is jampi ${ }^{2}$, tawar $^{3}$, tangkal $^{4}$, dan chucha ${ }^{5}$. If Malays society uses betoboh way (farming methods with mutual cooperation) and perari (way of mutual cooperation work in turn) Malay society use rhyme and poetry in interaction and as entertainment during work.

Malay peoples also sow rice (menugal) starting with the ritual of forest clearing (menatar utan). Followed by to weight or to consider the seeds, and ask for the seeds, making the rice pit (croaking the crown of rice). In Kampar and Indragiri, Tigalorong, rice is seen periodically with chanting rhyme:

\author{
Sayang denak sayang denai \\ Sayang beladang di tanah tumbuo \\ Wakotu kociok kolian bainai \\ Sayang pabilo kolian tumbuo
}

\footnotetext{
${ }^{1}$ The headman or chief of an indigenous.

${ }^{2}$ use of incantations in black magic, in control to the use of philters (ubat) or talismans (azimat); any such wonder-working formula.

${ }^{3}$ not effective (about witchcraft, mantra,spell etc.); lost power (about poison, etc.)

${ }^{4}$ Protective talisman or charm

${ }^{5}$ Spell to darken judgment, silence an enemy, or humble an adversary.
} 


\section{Husbandry}

Malay society sees hair whorl from the family member as a reflection of luck (paidi). The expression of prose literature is seen from paidi (a kind of mite) on owner or children about what animals breed when kept. Location and number of hair whorl become the hint ${ }^{6}$ for an individual child got luck in breeding. For children who have two hair whorl, should breeding horned animal such as a goat, buffalo, cow and etc. Then, one hair whorl which has elongated shape is considered paidi raising chickens. Another literary creation (mantra) in breed activities also exists when making shocks of animals traced in herding (poetry).

\section{Fishery}

The process of catching fish presents literary genre of mantra, poetry, rhyme, proverb. Literary activities begin when making fishing gear such as jala ${ }^{7}$, fishing-nets, fishing rod, serkap ${ }^{8}$, lukah ${ }^{9}$, sero $^{10}$, belat $^{l 1}$, and kelong $^{12}$. Fishing activities such as to catch in a net, to use casting net, fishing rod, scooping fish, menangguk ${ }^{13}$, melukah $^{14}$, mengelong ${ }^{I S}$ are also accompanied by literary activities. Some also do not use tools, such as mengecal and merawang also use literature. In Tapung, upstream of Siak river, Malay society look for fishing rods with spell accompaniment:

\begin{tabular}{ll}
\hline Joranku joran buluh si goteh & Belanga \\
Tumbuh di busut tepian larangan & Kuali \\
Kudiang joran lontulah lontu & Kancah \\
Kubilang ganjil gotelah joran & \\
\hline
\end{tabular}

Some specific society from community members is called fish paghuwo, a term for a person whose highest luck in getting the fish from person commonly. Fish Paghuwo commonly use spells, whistles, and poems to attract fish.

\section{Forestry}

Forestry or hunting livelihoods are alternative jobs that are needed for special purposes, such as the pressures of family economic or any member of the family who wants to feast. Animals snared with a variety of tools, such as dekut $^{16}$, puput $^{17}$, damak $^{18}$, cage and trap, tapping rubber and netting. In Pasirpengaraian, Rokan, this work is completed with literature like the rhyme-shaped spell, as following:

\begin{tabular}{ll}
\hline Abun-abun koti abun & Abun-abun koti abun \\
Tersangkut di pua mati & Tersangkut di pua mati \\
Segala ternak kabur dan rabun & Segala ternak sudah kuperabun \\
Janganlah engkau melihat lagi & Kuperabun sampai mati \\
\hline
\end{tabular}

\section{Agroindustry}

In agroindustry, beniro (slicing sugar-palm and coconut), Malay society include mantra as a culture in the beniro. In processing forest and garden products, spells to determine the oldest wood (manuo kayu) is read in the village of Sikijang, Logas, Rantau Kuantan. spell genre with the variant like narrative spells "Ooo Mano Datuk simangku tuo. Nan diom di banie tuo. Kok manangkuik manangkui sajo. Kok maliek-maliek sajo. Loba jangan diboi ula. Loba jangan diboi simbung. Totoplah ongkou di banie tuo."

\section{Gardening}

The Tradition of Malay society, the first thing to do is to plant rice when making a garden. gardening perennial plant or simply perennials is a symbol of luck and diginity of each tribe. In the custom of Malay society, it is advised by custom advice in the form of narrative that is collected by Effendy (2004) such as "If the tribe is not forested land, the

\footnotetext{
${ }^{6}$ A sign in breeding certain animals

${ }^{7}$ Casting net

${ }^{8}$ A conical trap or coop. As a trap for fish

${ }^{9}$ Basket-trap for fish

${ }^{10}$ A large marine fishtrap

${ }^{11}$ Screen made of rattan strips tied to one another longitudinally; screen-trap for fish.

${ }^{12}$ Large marine fishtrap with three or more triangular or heart-shaped comparments (kurong) into which the fish are led slong a line of screened

fishing-stakes

${ }^{13}$ Activity of landing net a large fish that has been hooked

${ }^{14}$ Activity of Basket-trapping for fish

${ }^{15}$ Activity of kelong

${ }^{16}$ The actual call of the pigeon

${ }^{17}$ A wind-instrument imitating bird-calls

${ }_{18}$ a dart with a detachable brass barb and running line used with a blowpipe for shooting fish
} 
same means as trade society (newcomer) living in the society's jungle, sheltering in the cove of society's river, waiting for the mercy of society, waiting for fields and society's bushes. So this tribe to upward does not sprout, to down is not rooted, in middle does not have the stem. Custom advice run out then dignity lost too, tribes who get contemptible then folk is no precious. "

\section{Carpenters}

Carpentry is a kind of work that is not done throughout of the year. Carpentry is only done when there is request or order. This work is done after preceded by menetau ceremony with spells:

\begin{tabular}{ll}
\hline Hentak tanah, temilang tanah & Di atas pinta kami \\
Tanah bernama bilang-bilang & Kami hendak menyolang ini tanah \\
Hontok engkau segala jemalang tanah & Akan kami solang untuk selama-lamanya \\
Jangalah engkau berulah-ulang & \\
\hline
\end{tabular}

Then followed by a ceremony of build a house. A master craftsman must also be skilled in spell, singing or presenting rhyme, proverb, and understand the moral teaching. A set of tepung tawar ${ }^{19}$ ceremonial, red cloth, white cloth, yellow cloth, black cloth, coconut, lime kink, water or kelalang. After the pawang ${ }^{20}$ sprinkles tepung tawar on the main pillar, other wood materials, and then recited a mantera ${ }^{21}$ as well. ceremonial closed with a prayer for safety read by a $L_{e b a i}{ }^{22}$.

\section{Trading}

Trade makes the strong contribution to distribution of classical literature that is not only in Riau but also in the archipelago. The influence of Arabic and Persian literature has given a strong color to the middle ages until the early 20th century. Not only the narrative texts of literacy but also to the transmission and transformation of written verse text into oral genres. altering of poetry by Haji Ibrahim Datuk Kaya Muda Riau transformed from saga text has provided strong Malay color and nourish the genres of classical literature, gurindam, framed stories and nazam, as well as literary books and act genre. Trading activities bring up literary genres such as taboo, rhyme, and poetry. In taboo, seller's habits don't trade activities such as selling salt, needles, nails at night.

\section{Discussion}

Study of literary genre in the Malay economic system of Tapak Lapan is the first study done. study of Tapak Lapan had begun by Hamidy (1986), however, he did not discuss the literary genre that existed in Tapak Lapan. Regarding literary genre, has been studied by many graduates of literatur in European since the 19th century. In the literary genre of Malay is the first done by Muhammad Haji Salleh (2006) who explains Malay aesthetics from various literary genres that are focused on traditional literature.

\section{CONCLUSION}

This study to explains the literary activities in the Malay economic system of Tapak Lapan in non-naratif and narrative form. This study illustrates that literary genres are the social nest in their social-physical environment. Both are related, extinction one of Tapak Lapan will affect the existence of literary genre. If the environment where Tapak Lapan is crushed then same as literary genre lost the context.

This research is useful for educational institutions to be used as teaching materials or reading materials in literature lectures and as an inner experience (experienced literature). For creative institutions such as sanggar-sanggar, this research can be used as a guide for exploration in contemporary works such as drama, dance, and music. For the government to be a reference in developing the malay economy.

\section{References}

Bogdan, R.C., \& Miklen, S.K. (2003). Qualitative research for education: an introduction to theory and methods. Boston: Allyn \& Bacon.

Braginsky, V.I. (1998). Yang Indah, berfaedah, dan kamal: sejarah sastra melayu dalam abad 7-19. Jakarta: Indonesian-Netherlands Cooperation in Islamic Studies (INIS).

Ambary, H.M (Ed.). (1999). Panggung sejarah persembahan kepada prof. dr. denys lombard. Jakarta: EFEO, Pusat Penelitian Arkeologi Nasional, dan Yayasan Obor Indonesia.

\footnotetext{
${ }^{19}$ Ordinary rice-flour watered and mixed with leaves of the setawar-plant then smeared on any person or thing for the purpose of driving away ill-luck

${ }^{20}$ Expert in any art believed to need the use of magic

${ }^{21}$ A magical formula of any short; a sacred text used as a charm or incantation

${ }^{22}$ The person who knows about religion
} 
Creswell, J.W. (2003). Research design: qualitative and quantitative approaches. London: Sage Publications. Effendy, T., et al. (2004). Tunjuk ajar melayu. Pekanbaru: Yayasan Tenas Effendy.

Esten, M. (1978). Kesusastraan: Pengantar teori dan sejarah. Bandung: Angkasa.

Esterberg, K.G. (2002). Qualitative methods in social research. Boston: McGraw-Hill.

Fang, L.Y. (2011). Sejarah kesusastraan melayu klasik. Jakarta: Yayasan Pustaka Obor Indonesia.

Gay, L.R. (1996). Educational research: Competencies for analysis and application. New Jersey: Prentice-Hall. Hamidy, UU, (1986). Membaca kehidupan orang melayu, Pekanbaru: Pustaka.

Harris, M. (1968). The rise of anthropological theory: a history of theories of culture. New York: Thomas Y Crowell. Junus, H. (1998). Raja Ali Haji budayawan di gerbang abad xx. Pekanbaru: Unri Press

Koster. G.L. (2011). Mengembara di taman-taman yang menggoda: pembacaan naratif melayu. Jakarta: KITLV.

Moleong, L. J. (2010). Metodologi penelitian kualitatif. Bandung: Remaja Rosda Karya.

Piaw, C. Y. (2006). Kaedah dan statistik penyelidikan: kaedah penyelidikan. Kuala Lumpur: McGraw-Hill (Malaysia) Sdn Bhd.

Salleh, M. H. (2006). Puitika sastera Melayu. Siri Lestari Sastra. Kuala Lumpur: Dewan Bahasa \& Pustaka.

Sugiyono. (2012). Memahami penelitian kualitatif. Bandung: Alfabeta.

Wellek, R. \& Warren, A. (2014). Teori Kesusastraan. (Terj.). Jakarta: Gramedia.

Wilkinson, R.J. (1959). A Malay - English Dictionary (Romanised). New York: ST MARTIN'S PRESS. 